\title{
De arrieros a mercaderes. Orígenes de los comerciantes de la región Tacna-Arica, 1776-1794.
}

\author{
por \\ Jaime Rosenblitt B. \\ Universidad Andrés Bello, Chile
}

Este artículo analiza los efectos de las reformas borbónicas en el partido de Arica, en el Virreinato del Perú, y examina el contexto económico que generaron, a partir del cual algunas personas dedicadas al transporte lograron convertirse en pequeños comerciantes.

Palabras Clave: Virreinato del Perú 1776-1794; partido de Arica; reformas borbónicas; economía; comercio; transporte; mercaderes; arrieros.

Normalmente, los estudios relativos al comercio en el mundo colonial se han ocupado de los grandes flujos de intercambio entre la metrópolis y sus colonias, y en las comunidades de mercaderes asentadas en las cabeceras administrativas virreinales, desde las cuales se perciben los mecanismos de comercio, los vínculos entre las elites económicas y la burocracia, los intentos de la autoridad por extraer recursos de sus posesiones y las oscilaciones en la lealtad a la Corona de sus súbditos más prósperos. Menos interés han tenido los mercaderes regionales, ya sea porque el reducido volumen de sus operaciones, su dependencia de los comerciantes primados y su escasa gravitación en las pulsaciones del imperio, hace, presumiblemente, poco atractivo su análisis. Sin embargo, consideramos que existen tres factores que obligan a examinar con detención a estos grupos: Primero, durante las cuatro últimas décadas del período colonial las economías regionales hispanoamericanas, como consecuencia de las reformas administrativas del siglo XVIII, alcanzaron amplio dinamismo y autonomía, por lo que su importancia en el conjunto de la economía colonial creció considerablemente. Luego, de estas economías surgieron elites regionales que, una vez disuelto el orden colonial, 
expresaron políticamente sus demandas, comprometiéndose en las luchas por la organización de las tempranas repúblicas americanas. Finalmente, en estas elites regionales los comerciantes desempeñaron un papel central, puesto que por la naturaleza de sus actividades, sus intereses se extendían hacia otros sectores de la economía regional, se mantenían informados de lo que ocurría en otros lugares, estaban al tanto del debate político y reflexionaban sobre las consecuencias que la imposición de una u otra postura tendría para sus intereses.

El caso del comercio de la región Tacna-Arica es además interesante porque se desarrolló en un territorio que, aunque alejado del núcleo político, tuvo una importante función en la organización económica del Virreinato del Perú, pues articulaba el intercambio entre los yacimientos argentíferos de Charcas y la cabecera administrativa en Lima. Hasta 1778, cuando fueron separados el Bajo y el Alto Perú, la producción de las minas de plata altiplánicas llegaba hasta Arica en caravanas de mulas, allí era embarcada en la Armada del Mar del Sur y seguía con destino a Lima, Panamá y España. En el sentido inverso, los tropeles trasladaban el mercurio para el beneficio de la plata, las manufacturas importadas desembarcadas en Arica y parte importante de la producción agrícola regional para sostener a la población de los enclaves mineros y los centros urbanos altoperuanos.

Ubicada al sur del virreinato peruano, en un paisaje desértico solo interrumpido por los cultivos en las quebradas que se extienden entre el altiplano y la costa del Pacífico, en las villas de Tacna y Arica, a 54 kilómetros entre sí, en la década de 1770 comenzó a germinar un grupo de mercaderes locales, estimulado por las reformas administrativas introducidas Carlos III. Hasta entonces, el grueso del intercambio comercial estuvo en manos del Corregidor, funcionario judicial que complementaba su sueldo mediante ventas forzosas, o repartimientos, de mercaderías entre los indígenas de su jurisdicción $\mathrm{y}$, en muchos casos, también abastecía a los habitantes criollos de su partido ${ }^{1}$. En la provincia de Arica dicha situación fue constatada por un viajero a mediados del siglo XVIII, que observó que «La gobernación de esta ciudad es una de las más considerables del Perú a causa del gran comercio que allí se efectúa. Al llegar encontré siete barcos franceses, que tenían entera libertad de tráfico. El mismo gobernante, que es muy rico y de una probidad infinita en el comercio, hacía compras considerables para enviar a las minas» ${ }^{2}$.

Este protagonismo mercantil del Corregidor quedó en evidencia en el juicio de residencia seguido contra Demetrio Egan, que ocupó el cargo en-

1 Moreno Cebrián, 1977.

2 Morghen, 12 (Lima, 1982-1983): 290. 


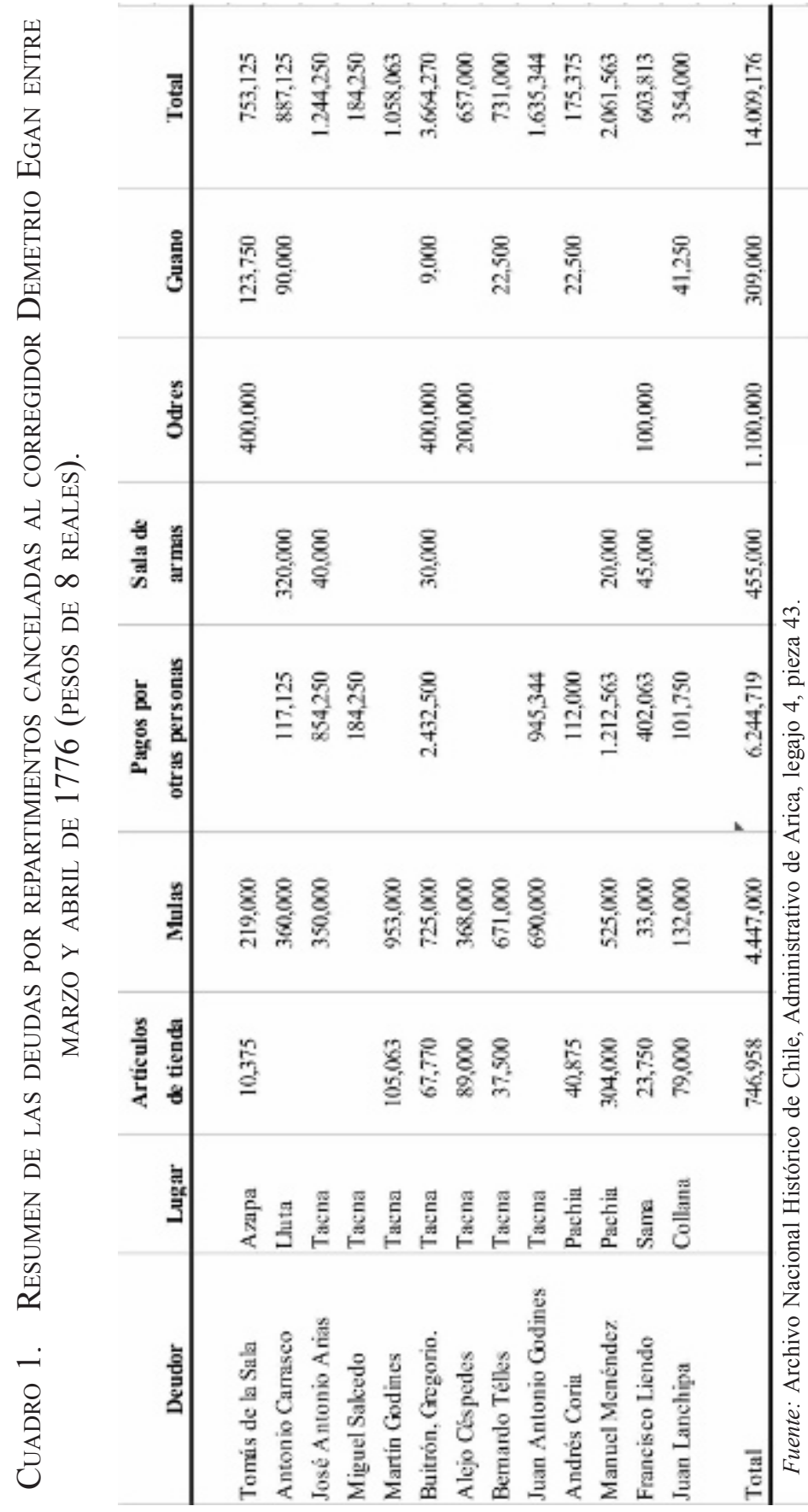


tre 1771 y 1776, quien luego enfrentó acusaciones por evasión de la alcabala y cobros con violencia. La defensa de Egan incluye un Libro de Cuentas, que ofrece una idea aproximada sobre los efectos repartidos, la cobertura espacial de la distribución y las características de las personas y comunidades involucradas. El cuadro anterior muestra una síntesis de las deudas pagadas a Egan durante los últimos dos meses de su período.

No todos los rubros anotados corresponden a artículos sujetos al repartimiento. En la contabilidad se incluyó la contribución para la Sala de Armas, es decir, el aporte que los principales vecinos hacían para el sostenimiento de un recinto para almacenar el arsenal empleado por la milicia local, y cuya recaudación estaba a cargo del Corregidor. Excluidos los 455 pesos por dicho concepto, resulta que al concluir su período Demetrio Egan tenía deudas a su favor por más de 13.500 pesos. La documentación no permite conocer exactamente las características de cada deudor, pues poco menos de la mitad del total corresponde a pagos hechos por encargo, sin especificar el origen de la deuda. Sólo es posible conocer el detalle de los efectos repartidos en los casos en que el deudor se presentó al ajuste de cuentas. Estos últimos suman 7.192 pesos $2 \frac{1}{2}$ reales, compuestos en un $70 \%$ por mulas, $15 \%$ de odres, $11 \%$ en efectos de tienda, y $4 \%$ de guano.

No obstante la limitación de estas cifras, la composición de la deuda se aproxima mucho a la estructura económica de la región que describen las crónicas y que se vislumbra en las fuentes. La alta participación de mulas en los repartos es consistente con la gravitación de la arriería, actividad que comprometía a la mayoría de sus habitantes y obligaba al sector agrícola a reservar parte de sus recursos a la producción de forraje. Al igual que la arriería, la distribución de odres y guano demuestra la vinculación con los mercados altiplánicos a través de la producción y comercialización de aceite, vino y aguardiente; el guano era empleado como abono agrícola para mejorar el rendimiento del cultivo de vides en suelos delgados, mientras que las odres servían de recipientes para los líquidos despachados a la sierra. Finalmente están los «artículos de tienda», que corresponden principalmente a telas, ropa de Castilla y de la tierra, vajilla, herramientas y papel.

Otro aspecto que revelan estos antecedentes dice relación con las características económicas de los diversos espacios regionales, las que son posibles de reconocer a partir de los bienes suministrados por el Corregidor, cuya distribución intrarregional se detalla en el siguiente cuadro.

Estas cifras sitúan al pueblo de Tacna y al sector de Pachia, ubicado hacia el noreste sobre el curso del río Caplina, como el área más poblada de la región y su principal núcleo de consumo, puesto que allí se aglutina más del $85 \%$ de las manufacturas suministradas por el Corregidor. La concentración 
CuAdro 2. Distribución InTRARREgional de las DEUdAs POR REPARTIMIENTO en el Corregimiento de Arica, marzo y abril de 1776 (pesos de 8 REALes)

\begin{tabular}{l|r|r|r|r|r|} 
& $\begin{array}{c}\text { Artículos } \\
\text { de tienda }\end{array}$ & Mulas & Odres & Gummo & \multicolumn{1}{|c|}{ Total } \\
\hline A 7apa & 10,375 & 219,000 & 400,000 & 123,750 & 753,125 \\
Lluta & & 360,000 & & 90,000 & 450,000 \\
Tacna & 299,333 & $3.757,000$ & 600,000 & 31,500 & $4.687,833$ \\
Pachia & 344,875 & 525,000 & & 22,500 & 892,375 \\
Sama & 23,750 & 33,000 & 100,000 & & 156,750 \\
Tarata & 79,000 & 132,000 & & 41,250 & 252,250 \\
Total & 757,333 & $5,026,000$ & $1.100,000$ & 309,000 & $7.192,333$ \\
\hline
\end{tabular}

Fuente: Archivo Nacional Histórico de Chile, Administrativo de Arica, legajo 4, pieza 43.

de este tipo de artículos en la zona no obedece sólo a que en las villas y sus suburbios se reuniera la población con mayor poder adquisitivo, o que esta acostumbrara a usar este tipo de enseres, sino porque el área Tacna-Pachia también articulaba parte importante del comercio y la arriería de la región, puesto que la proporción de mulas colocadas allí fue incluso levemente superior a la de efectos de Castilla, Esto sugiere que una parte de dichos bienes no estaba destinada al consumo local, sino que se integraba a las rutas de arriería hacia el altiplano. Evidencia de lo anterior es que Tacna reúne más de la mitad de los repartimientos de odres y, considerando que las condiciones climáticas de su entorno no son las más apropiadas para el cultivo vides y olivares, concluimos que estamos en presencia de un grupo de arrieros en tránsito a convertirse en mercaderes, que adquiría aceite, vino y aguardiente en lugares no demasiado distantes, como Azapa, Moquegua e Ilabaya, y los remitía a los centros de consumo.

Una lógica parecida es la que opera en el valle de Sama, donde los suelos dedicados al cultivo de trigo y algodón servían de base económica a individuos que combinaban la arriería y el comercio. Es el caso de Francisco Liendo, un deudor de Egan que canceló una mula, dos odres y algunos artículos de tienda, bienes que excedían las necesidades de su familia, y que corresponderían a actividades comerciales hacia el altiplano de baja escala. Este caso ilustra la transición de la arriería al comercio, puesto que dos décadas más tarde poco quedaba del pequeño agricultor que ocasionalmente emprendía travesías a la sierra para vender su cosecha de trigo, géneros recibidos del Corregidor y aguardiente llegado desde los valles vecinos. En 1795 Liendo 
se había transformado en un mercader de cierta importancia, que figura en una escritura colocando en Potosí 1.000 pesos en aguardiente de Moquegua ${ }^{3}$.

En Azapa, los repartos del Corregidor también muestran las singularidades de la estructura económica del territorio. Su conformación básica de guano y odres revela la existencia de un núcleo de propietarios agrícolas dedicados al cultivo de olivares, cuya producción de aceite tenía gran aceptación en los mercados altoperuanos ${ }^{4}$. La pequeña cifra de artículos de tienda disimula la importancia del comercio en ese valle, pues las fuentes judiciales dan cuenta de vecinos criollos que accedían a efectos importados vía contrabando. Por lo tanto, los poco más de 10 pesos en efectos de Castilla colocados por el Corregidor, corresponden a la particular situación de Tomás de la Sala. De él sabemos que inicialmente combinaba el cultivo de olivos con la arriería, y que más tarde se especializó en el comercio. En 1784 adquirió a crédito aguardiente por valor de 817 pesos, suma que restituyó con las utilidades de dos viajes a la sierra ${ }^{5}$. Incluso, al testar en 1797, Sala se identifica como mercader y sólo el hecho de poseer numerosas mulas refiere a su época de arriero $^{6}$.

A diferencia de Azapa, donde confluyen la agricultura y el comercio, la economía del valle de Lluta es más limitada, puesto que la salinidad del río hacía que el único cultivo posible fuera el de forraje, de modo que para sus habitantes la arriería constituía un complemento necesario a sus limitadas posibilidades agrícolas, lo que se refleja en el reparto hecho a Antonio Carrasco, que consistía únicamente en mulas y guano.

Algo similar sucede en Tarata, donde haciendo la salvedad de 79 pesos en artículos de tienda, el reparto también consiste en mulas y un poco de guano. Sin embargo, las singularidades del sector se advierten a partir de otros elementos. En primer lugar, en el ajuste de cuentas la zona se identifica como «collana», voz que en quechua y aimara significa principal o primero en jerarquía, y cuando se refiere a una población alude al pueblo o aldea que hace de cabecera, que en este caso corresponde a la doctrina de Tarata ${ }^{7}$. Aquí, el cacique Juan Lanchipa se presentó ante el secretario del Corregidor y saneó cuantas propias y de su comunidad, que por las características ecológicas del

\footnotetext{
3 Demanda de Francisco Liendro a Manuel Menéndez, 22 de diciembre de 1795, Archivo Nacional Histórico de Chile (ANHC), Judicial de Arica, legajo 94, pieza 9.

4 Hidalgo, 12 (Arica, 1996): 31-50.

5 Reconocimiento de deuda, 19 de enero de 1794, ANHC, Notarial de Arica, legajo. 44, folios $225-227 \mathrm{v}$.

6 Testamento de Tomás de la Sala, 30 de marzo de 1797, ANHC, Notarial de Arica, legajo 53, folios 54-59.

7 Paz Soldán, 1877: 196 y 198.
} 
entorno, también estaba dedicada al cultivo de forraje, la cría de ganado y la arriería.

En síntesis, la liquidación de las cuentas de los repartos de mercancías presentada por la defensa de Egan, confirma que la arriería constituía la principal actividad de los tacnoariqueños, la que combinaban con la práctica de cultivos destinados a su colocación en el altiplano, y que además se complementaba con otros alimentos adquiridos en las comarcas vecinas, así como los bienes elaborados suministrados por el Corregidor u otros mercaderes. Estas características constituyen un punto de partida para establecer las transformaciones que experimentó la estructura económica regional a partir de las reformas administrativas y económicas que comenzó a introducir la Corona española en América desde la segunda mitad de la década de 1760.

LAS REFORMAS ADMINISTRATIVAS, SUS EFECTOS EN LA REGIÓN TACNA-ARICA Y SU COMERCIO

Del conjunto de estas reformas, la separación del Alto y el Bajo Perú, hecha efectiva en 1778, fue la que tuvo mayores efectos sobre el antiguo partido de Arica. Esto, por la estrecha vinculación de su economía con el camino de la plata que conectaba los enclaves mineros altiplánicos con la capital del virreinato, y los servicios que prestaban sus arrieros y agricultores al sostenimiento de las caravanas que cubrían las rutas entre el puerto de Arica y los centros mineros y urbanos de Charcas. Sin embargo, los efectos negativos provocados por esta decisión fueron mitigados con la promulgación del Reglamento de Libre Comercio y Navegación, también en 1778, que otorgó a Arica la categoría de «puerto mayor», por lo que dejó de depender de otros centros de mayor jerarquía para recibir artículos importados. A ello se suma que al abrirse Buenos Aires y Montevideo al comercio directo con la metrópolis, los efectos de ultramar que antes llegaban desde Lima, comenzaron a arribar desde esos puertos a través de las rutas de la sierra, a precios mucho más convenientes.

Otra medida impulsada por los reformadores borbónicos fue la instauración del régimen de Intendencias, en 1784. Dicha disposición tenía como propósito racionalizar la administración colonial, especialmente en materia de hacienda, confiando la gestión a funcionarios rentados, menos condescendientes con los intereses locales. Se eliminó la figura del Corregidor y la institución del repartimiento, considerada el origen de la corrupción y los abusos en América; y se incitaba el desarrollo actividades productivas alternativas a la minería, especialmente en aquellas regiones que habían permanecido margi- 
nadas de los principales circuitos económicos ${ }^{8}$. En el caso del partido de Arica, esto permitió que actores locales incursionaran en el comercio altiplánico, que ahora ofrecía la oportunidad de complementar los despachos de alimento con el retorno de importaciones.

A partir de 1778 es posible identificar específicamente al sector mercantil en la documentación fiscal, ya que como complemento a la liberalización del comercio y al desembarque de efectos de ultramar en Arica, comenzaron a cobrarse por separado las alcabalas del viento, de tarifa y del mar. Estas obligaciones, en conjunto con los almojarifazgos, ofrecen una noción más próxima a las dimensiones y el comportamiento del intercambio comercial en la región.

CUAdRo 3. APORTE DEL SECTOR COMERCIAL A LOS INGRESOS de la Caja Real de Arica, 1775-1786 (pesos de 8 REALEs)

\begin{tabular}{|c|c|c|c|c|c|c|c|c|}
\hline & de tanta & $\begin{array}{l}\text { Alcabolns } \\
\text { del mat }\end{array}$ & del visuta & Alnojarifazgo & Airoj entrada & Almoj. salida & $\begin{array}{c}\text { Totnl sector } \\
\text { comsrial }\end{array}$ & Toral caja \\
\hline 1775 & & & & 1.390 & & & 1.390 & 20543 \\
\hline 1776 & & & & 1.408 & & & 1.408 & 17592 \\
\hline$m$ & & & & 2.635 & & & 2.615 & 20056 \\
\hline 1778 & 1.778 & & & & & & 1.778 & 19.176 \\
\hline 1779 & 2665 & & & & & & 2.665 & 51.496 \\
\hline 1780 & 1.334 & & & & & & 1.31 .4 & 121.850 \\
\hline 1781 & & & & & & & - & - \\
\hline 1782 & & & 18.445 & 4,713 & 4.530 & 183 & 27.871 & 64415 \\
\hline 1789 & 1.334 & & 17.871 & 6.980 & 6.698 & 282 & 33.165 & 53318 \\
\hline 1784 & & 3.757 & & 8.186 & 7.620 & 566 & 20.129 & 48.185 \\
\hline 1785 & & 2.800 & 1.199 & 3.347 & 3.266 & 81 & 10.093 & 49917 \\
\hline 1786 & & 2668 & 1.892 & 8.738 & 8.715 & 23 & 22036 & 83091 \\
\hline
\end{tabular}

Fuente: Te Paske y Klein, 1982, vol 2.

Las cifras recopiladas confirman el estrecho vínculo entre el sector comercial y la base agrícola regional, pues algunos de los años de mayor aporte sectorial a la Real Hacienda, como 1782 y 1783, coinciden con elevados rendimientos de la alcabala del viento.

El desenvolvimiento mercantil también estaba subordinado a la situación política del virreinato y el imperio español, la que dio lugar a períodos de

8 Fisher, 1981: 142. Garavaglia y Marchena, 2005, vol. 2: 45-48. 
inestabilidad e incertidumbre. Tal fue el caso de la sublevación indígena de 1780-81, la presencia de naves inglesas en el Pacífico, en actitud beligerante hasta 1783 y luego dedicadas al contrabando. A estos factores se sumó la declinación de los mercados altoperuanos a partir la segunda mitad de la década 1780, como consecuencia de la crisis del sector minero.

Los años más auspiciosos de este período, 1782 y 1783, corresponden a una etapa de estabilidad política en la que los mercaderes locales lograron aprovechar al máximo los flujos de intercambio que transitaban por la región Tacna-Arica. Durante este período, el impuesto más significativo sobre el comercio fue la alcabala del viento, que recaía sobre las transacciones de las cosechas. Esto confirma que el sustento del comercio era la agricultura regional, cuyo principal mercado continuó siendo la demanda altoperuana. Los alimentos se complementaban con productos importados que llegados a Arica, como el cacao de Guayaquil, carne salada y cereales de Chile, y el azúcar de Piura, cuyo ingreso quedó registrado el ramo de almojarifazgo de entrada.

En cuanto a los bienes manufacturados, la documentación fiscal muestra que el circuito de aprovisionamiento del Alto Perú se invirtió. Los productos importados que hasta las reformas de 1778 llegaban desde Lima, comenzaron a arribar masivamente desde Buenos Aires, pasando desde el altiplano con todas sus obligaciones tributarias satisfechas. En este escenario, el comercio tacnoariqueño perdió el control del tráfico de manufacturas hacia Charcas. Tampoco pudo competir con sus pares arequipeños por el dominio de la distribución de importaciones en el sur bajoperuano. Su mayor envergadura e influencia, sus ventajas para aprovisionarse de azúcar y cereales, y el acceso a un mercado de consumo para los efectos de ultramar mucho más amplio, resultaron factores incontrastables ${ }^{9}$. Por consiguiente, los mercaderes de Tacna y Arica se limitaron a la distribución de manufacturas al interior de la propia provincia y hacia Tarapacá, que pese haber alcanzado autonomía administrativa en 1768, aun dependía del comercio tacneño para proveerse de esos bienes y de los alimentos cosechados al interior del partido o desembarcados en Arica.

\section{LA EVOLUCIÓN DE LA ARRIERÍA AL COMERCIO}

Dadas sus funciones en la organización económica del virreinato, la arriería se constituyó tempranamente en una actividad fundamental del partido de Arica. La necesidad de transportar el azogue que llegaba al puerto hasta los

9 Fisher, 1981: 149. 
yacimientos mineros altoperuanos, indujo a muchos habitantes a adquirir mulas y dedicarse al acarreo del mercurio, y más tarde, complementarlo con el trajín de todo tipo de productos ${ }^{10}$. De este modo, buena parte de la población alternaba la práctica de la arriería, la agricultura y el comercio. El surgimiento de un segmento empresarial especializado en el comercio se vislumbró al concluir la década de 1770, cuando comenzaban sentirse los efectos de reformas fiscales, y se consolidó con la abolición de los corregimientos en 1784, que dejó un amplio margen de emprendimientos mercantiles para ser cubierto por actores regionales, como los arrieros, que ya participan de en los circuitos de intercambio regional.

Los arrieros pudieron complementar los tradicionales despachos de alimentos hacia Charcas, con el tráfico de otras mercaderías llegadas desde Lima, como azúcar, cacao y tinturas. Además, como la apertura de los puertos rioplatenses copó la demanda altoperuana por bienes importados, algunos troperos tacnoarriqueños aprovecharon los bajos precios invirtiendo parte de sus utilidades en la compra de efectos de ultramar, que luego colocaban en su propia región. Sin embargo, este flujo se paralizaba cuando flotas británicas o francesas bloqueaban los puertos de Buenos Aires y Montevideo, producto de algún conflicto bélico con España. En esas ocasiones el aprovisionamiento de importaciones hacia el altiplano volvía a depender del eje Tacna-Arica, que a su vez se abastecía de los navíos de registro que llegaban al océano Pacífico por la ruta del Cabo de Hornos.

Bajo estas condiciones, los troperos tacnoariqueños disponían de un abanico de alternativas con las que complementar su actividad original, las que suponían distintos grados de riesgo y, por lo tanto, de rentabilidad. La forma más segura era incursionar en el comercio invirtiendo en bienes de fácil colocación, pero sin abandonar la especialización en el transporte. La más riesgosa era destinar las utilidades a la adquisición de importaciones, para después ofertarlas en las plazas de destino o en la región. Entre ambas opciones, estaba la posibilidad de adquirir tierras de cultivo para producir forraje y los alimentos más demandados en los lugares de destino. Para entender las lógicas que operaron en el transito del arriero al mercader, así como las variables que explican porque algunas experiencias fueron exitosas y otras fracasaron, es necesario examinar algunos ejemplos.

El caso de Andrés Coria, vecino de Pachia que figura en la liquidación de cuentas con el corregidor Egan pagando 40 pesos con 7 reales por artículos de tienda y 22 pesos con 4 reales por guano, representa la opción por la arriería tradicional, ya que a lo largo de su trayectoria empresarial se

10 Seiner, 2006: 873-874. 
limitó al transporte de mercaderías hacia la sierra. Su testamento, dictado en 1783, detalla su forma de operar. Declara que cuando contrajo matrimonio con Inés Figueroa no recibió dote y el único capital familiar lo conformaban las diez mulas aparejadas, con sus respectivos odres, que él aportó, lo que indica su especialización en el acarreo de vinos y licores. Esto se confirma al describir la composición de sus bienes, destacando que su principal patrimonio eran las 45 mulas, seis mulas de montar y un caballo, todos con sus aperos ${ }^{11}$. La revisión de las acreencias y deudas declaradas por Coria, confirma que sus actividades correspondían a servicios de transporte prestados a otras personas más que a emprendimientos propios. Entre sus deudores figuran varios comerciantes tacnoariqueños, por concepto de fletes no cancelados; la lista de pagos insatisfechos incluye viñateros que lo contrataron para el traslado de su producción al altiplano, mientras que sus acreedores eran agricultores de Sama y Lluta, que lo abastecían con forraje para sus bestias.

El horizonte empresarial de Coria fue dejar de depender de otros para sostener su recua. Las utilidades obtenidas en el acarreo de alimentos las destinó a adquirir dos haciendas en Calana y Pachia. Inicialmente heredó de sus padres algunas porciones de dichos predios, los que reunificó mediante la compra de los derechos al resto de la sucesión. El destino que Andrés Coria dio a estos suelos demuestra su intención de concentrarse en la arriería, pues al comparar su testamento con el inventario de los bienes de su padre, Silverio, se constata que una de las haciendas estuvo plantada con vides, las que reemplazó con alfalfa ${ }^{12}$. Este cambio fue confirmado por el intendente Antonio Alvarez y Jiménez, que en agosto de 1793 determinó que ambos predios estaban exentos del pago del impuesto al aguardiente, entonces demandado por los oficiales de la Caja Real de Arica ${ }^{13}$.

La decisión de Andrés Coria de dedicar sus terrenos al cultivo de forraje, dejando de lado la alternativa de producir los bienes alimenticios demandados en los mercados a que acudía, o bien, la de incursionar en el comercio de manufacturas, revela la existencia de un segmento de arrieros que se limitaron a su quehacer tradicional, ofertando únicamente la prestación de servicios de transporte. Dicha rutina permaneció en la familia Coria, ya que Pedro Pablo, hijo de Andrés, figura en los protocolos notariales tacneños de 1818 recibien-

11 Demanda contra los herederos de Andrés Coria, 15 de abril de 1795, AHNC, Judicial de Arica, legajo 41, pieza 3.

12 Inventario de bienes de Silverio Coria, 1 de diciembre de 1790, ANHC, Notarial de Arica, legajo 47, folios 340-341.

13 Barriga, 1948, t. III: 32. 
do mulas a crédito, las que se comprometió a pagar con el acarreo de mercancías a la sierra ${ }^{14}$.

En el caso de Apolonia Infantas, en cambio, se registra efectivamente un tránsito desde la arriería al comercio, aunque el camino no fue recorrido completamente. La empresaria se especializó en atender la demanda altiplánica por alimentos, ropa de la tierra, vino y aguardiente, destinando sus utilidades a producir directamente algunos de esos bienes mediante la adquisición de varias propiedades agrícolas, que también arrendaba en porciones o en su totalidad. Ello le permitió acumular una pequeña fortuna, la que, al final de sus días, estaba conformada por cinco haciendas en Sama y cerca de Tacna, y varias propiedades en ese pueblo ${ }^{15}$. Con este patrimonio fundó una capellanía de 400 pesos anuales en favor de su hijo Gregorio, interno en el Seminario de Potosí, y dotó generosamente a dos hijas para iniciar su vida conyugal. Llama la atención en el testamento de la mujer, que reconoce de su propiedad sólo nueve mulas, cantidad muy baja considerando el volumen y el valor de sus bienes ${ }^{16}$, lo que revela la decisión de no seguir el camino de la arriería tradicional, ya sea porque sus cualidades comerciales no estaban en el transporte, o porque consideraba que los animales eran una posesión poco segura.

La carrera empresarial de Apolonia Infantas se inició en 1778, luego de la muerte de su marido. Del matrimonio quedaron cinco hijos, cuatro hijas y bienes tasados en 8.473 pesos, 6.300 de los cuales destinó a cubrir las deudas del difunto. El resto se componía de algunos géneros y varios candelabros de plata, que fueron trocados por una remesa de aguardiente avaluada en 400 pesos. El cargamento fue despachado a Potosí en una recua comandada por su hijo mayor, Bartolomé. Las utilidades fueron invertidas en mercaderías y en la organización de nuevos envíos. Así, la empresa familiar se constituyó a partir de una estructura muy sencilla, con la madre a cargo de la administración del capital, la adquisición de mercadería y la toma de decisiones, su hijo Bartolomé conduciendo las caravanas hacia el Alto Perú, otro hijo, Ignacio, comisionado en Moquegua para obtener aguardiente, en tanto que los hijos e hijas menores permanecían en la casa de Tacna

14 Reconocimiento de deuda a favor de José Santiago Basadre, 16 de diciembre de 1818, AHNC, Notarial de Arica, legajo 65 folios 128v-129.

15 La principal vivienda familiar, construida por Francisco Céspedes, sirvió en 1777 como fianza para que Fausto Calderón de la Barca ocupara el cargo de Contador de la Caja Real. Cavagnaro, 1986, vol. 4: 234.

16 Testamento de Apolonia Infantas, 24 de julio de 1798, ANHC, Judicial de Arica, legajo 87 , pieza 1 . 
o en el predio familiar de Calana. Aunque la pequeña empresa arrojó beneficios en poco tiempo, pronto aparecieron dificultades derivadas de la carencia de una organización sistemática, puesto que en 1780 Bartolomé e Ignacio fueron separados del negocio acusados, el primero de quedarse con parte de las ganancias obtenidas en la sierra, y el segundo con el dinero para cancelar el impuesto al aguardiente. De los otros tres varones, Apolonia contó con la colaboración del menor, José, ya que Gregorio estaba en el Seminario y Leandro en la milicia en Arequipa ${ }^{17}$.

Los casi veinte años de trayectoria empresarial de Apolonia Infantas se estructuraron en torno a tres tipos de prácticas que le permitieron mantener una actividad regular, aprovechar oportunidades para incrementar su capital, resguardar el patrimonio familiar y abastecerse de algunos de los bienes que colocaba en el altiplano. Estos fueron el comercio de aguardiente, alimentos y géneros, el préstamo a interés y la adquisición de predios agrícolas. La compra venta de vinos y licores fue el principal rubro en el que Apolonia Infantas concentró su atención, por su expedita colocación y la facilidad con que podía obtenerlos en los valles próximos a Tacna.

En lugar de amarrar parte importante de su capital a mulas propias, la empresaria optó por invertir sus recursos en la adquisición de aguardiente, para cuya distribución se asociaba con arrieros independientes encargados de acarrearla, mediante operaciones de habilitación en las que entregaba los licores a los troperos, con sus obligaciones tributarias cumplidas y a precios apenas por encima del costo. Esperaba hasta el retorno de las expediciones para extraer su parte de las utilidades, según un valor establecido previamente, lo que permitía a su contraparte buscar por su cuenta mejores precios y obtener beneficios adicionales a los servicios de flete. Así, en enero de 1784 llegó a un acuerdo con el azapeño Tomás de la Sala, mediante el cual la mujer le proporcionaría aguardiente por valor de 817 pesos, 700 de los cuales serían pagados al momento de la entrega y el saldo por partes iguales con el producto de dos viajes al Alto Perú ${ }^{18}$. Este vínculo permitió a Sala derivar hacia el comercio llevando por su cuenta otros productos. Fue así como en febrero de 1787 enteró 12 pesos en la Caja Real, correspondientes a la alcabala de 10 quintales de jabón que había puesto en Potosí19. El alejamiento de Sala fue cubierto al año siguiente por Francisco Liendo, quien

\footnotetext{
17 Idem.

18 Reconocimiento de deuda, 19 de enero de 1784, ANHC, Notarial de Arica, legajo 44, folios $225-227 \mathrm{v}$.

19 Registro de pago de alcabala, 8 de febrero de 1787, Biblioteca Facultad de Derecho de la Universidad de Chile (BDUCH), Caja Real de Arica, legajo 5, fol. 9.
} 
comenzó trasladando hasta Potosí 60 botijas de vino recibidas de Apolonia Infantas ${ }^{20}$.

Las pocas mulas que poseía la mujer, eran empleadas para cubrir tramos más cortos, menos exigentes y, posiblemente, más rentables, como las rutas hasta Locumba e Ilabaya donde se proveía de licor, o hasta la Aduana de Arica, donde adquiría ciertos bienes que le proporcionarían mayores ingresos si los comercializaba por su cuenta. Es el caso de las 15 arrobas de azúcar de Paita, que junto a 5 cabos de bayeta de la tierra, 11 cestos de coca y 40 quintales de aguardiente, fueron despachadas a las ciudades de La Paz y Potosí21 ${ }^{2}$. Además, la empresaria era una importante proveedora regional de ropa de la tierra para las recuas que partían a la sierra. Así se desprende de una demanda que interpuso el 7 de noviembre de 1782 contra la sucesión de Cayetano Yañez, por 518 pesos con 4 reales que el difunto le adeudaba al momento de fallecer y que sus albaceas no consideraron $^{22}$. Su proveedor era José Luis Quispe, cacique de Santiago de Puja, en Puno, que los conducía personalmente hasta Tacna y dejaba en consignación ${ }^{23}$.

Apolonia Infantas también incursionó en el crédito, aunque todas las evidencias sugieren que fue una manera de auxiliar a familiares y conocidos en apuros, más que obtener beneficios. Tal parece haber sido el caso de los mil pesos que entregó a su sobrina, Ventura López de Barreda, en marzo de 1787. La mujer estaba casada con Tomás de Menocal, subdelegado del partido, con cuyo aval se comprometió a devolver la suma en un año, al $6 \%$ de interés y con la garantía de cinco esclavos, condiciones normales para cualquier operación crediticia de la época ${ }^{24}$. Más filantrópica fue cuando entregó 200 pesos a Gaspar de Salazar, al 5\% y por el plazo de dos años 25 ; o al ayudar a Dionisio Escauriza, por quien canceló una deuda de 3.616 pesos, sin dejar formalmen-

20 Registro de pago de alcabala, 14 de enero de 1788, BDUCH, Caja Real de Arica, legajo 5 , fol. $34 \mathrm{v}$.

${ }^{21}$ Registro de pago de alcabala, 23 de mayo de 1787, BDUCH, Caja Real de Arica, legajo 5 , fol. $16 \mathrm{v}$.

${ }_{22}$ Demanda contra los herederos de Cayetano Yañez, 7 de noviembre de 1782, ANHC, Notarial de Arica, legajo 41, folios 171-202v.

${ }^{23}$ La operación corresponde a cinco cargas de ropa que el cacique llevó hasta Tacna. Consignación de mercadería, 5 de abril de 1788, ANHC, Notarial de Arica, legajo 43, folios $67 \mathrm{v}-68 \mathrm{v}$.

24 Préstamo a Ventura Barreda, 23 de marzo de 1787, ANHC, Notarial de Arica, legajo 43, fol. 326.

25 Préstamo a Gaspar y Josefa Salazar y Tomás Chorruca, 2 de marzo de 1789, ANHC, Notarial de Arica, legajo 45, folios 54v-56v. 
te escriturada la modalidad de pago ${ }^{26}$. Infantas consideraba que los préstamos y avales constituían un medio para socorrer a parientes y amigos, o bien incrementar su influencia social, ya que el riesgo de este tipo de operaciones era elevado, considerando los bajos retornos que se podían obtener. Por lo tanto, la inversión de su capital se orientó a la adquisición de propiedades agrícolas y urbanas, que garantizaban la estabilidad de su patrimonio, ofrecían la posibilidad de abastecerse de algunos insumos para el comercio altiplánico y disponer de un inmueble sobre el cual girar en momentos de apremio.

Sus primeras tierras agrícolas fueron un predio en Calana y una hacienda cerca de la aldea de Sitana, unos 80 kilómetros al noreste de Tacna. Ambas propiedades eran herencia de sus padres y las destinó a pastizales para sus animales ${ }^{27}$. Gran empeño puso en adquirir la hacienda Yanaguay, en Sama, que había sido dividida en dos hijuelas. La primera, destinada al cultivo de cereales y alfalfa, fue adquirida a Francisco Yañez y Zeballos en noviembre de 1788 en 4 mil pesos, en tanto que la segunda, sembrada con algodón y forraje, y dotada con una pequeña red de riego, se la compró tres años después, por la misma suma, a Juan Tomás Costa ${ }^{28}$. Con la rehabilitación de la hacienda Yanaguay, Apolonia obtuvo retornos sobre su inversión al arrendarla por partes. A Evaristo Godines cedió un sector con tierras de pan llevar, dos alfalfares y tres algodonales, por nueve años en $1.950 \operatorname{pesos}^{29}$; a Silvestre Saco arrendó, también por nueve años, un sector de sementeras por un canon de 200 pesos anuales ${ }^{30}$; y al arriero Santiago González cedió, en agosto de 1797, un alfalfar en Sama por 311 pesos anuales ${ }^{31}$.

La trayectoria empresarial de Apolonia Infantas estuvo condicionada por las circunstancias en que debió hacerse cargo de los asuntos de su esposo, la necesidad de procurar un buen pasar a sus hijos, y la falta de personas de confianza junto a las cuales ejecutar operaciones comerciales de mayor riesgo.

26 Cancelación de deuda, 9 de octubre de 1789, ANHC, Notarial de Arica, legajo 43, folios 231-231v.

27 Testamento de Apolonia Infantas, 24 de julio de 1798, ANHC, Judicial de Arica, legajo 87 , pza. 1 .

28 Venta de tierras a Apolonia Infantas, 3 de noviembre de 1788, ANHC, Notarial de Arica, legajo 43, folios 191v-194v.; Venta de tierras a Apolonia Infantas, 8 de noviembre de 1791, ANHC, Notarial de Arica, legajo 47, folios 247v-249.

29 Arriendo de tierras a Evaristo Godines, 22 de abril de 1795, ANHC, Notarial de Arica, legajo 51, fol. 281.

30 Arriendo de tierras a Silvestre Saco, 20 de mayo de 1798, ANHC, Notarial de Arica, legajo 54, folios 60-61v.

31 Arriendo de tierras a Santiago González, 4 de agosto de 179, ANHC, Notarial de Arica, legajo 53, folios 231-231v. 
Al asumir la administración de los negocios familiares, intentó continuar con la modalidad seguida por su cónyuge, es decir, la colocación de vinos y licores en los mercados altoperuanos con mulas propias, opción que abandonó cuando expulsó a sus hijos mayores de la empresa. Esto le impidió continuar con las actividades de arriería de su marido, por lo que se concentró en la adquisición de vino, licores, alimentos y ropa de la tierra, para cuyo transporte recurrió a acuerdos con troperos especializados. La incursión de Apolonia Infantas en el comercio fue coyuntural y producto de urgencias familiares. Privilegió aprovechar sus fortalezas, reducir los riesgos aun a costa de las utilidades, invirtiendo en sectores de rentabilidad baja pero segura.

\section{EL VÍNCULO CON LA MINERÍA DE TARAPACÁ}

Las transformaciones en la estructura de la región Tacna-Arica se aprecian al examinar el rendimiento tributario de los distintos sectores económicos entre 1775 y 1786 . El siguiente cuadro agrupa los ingresos de la Caja Real de Arica, separando las obligaciones que recaían sobre las comunidades indígenas. A partir de 1782 se aprecia una creciente gravitación del sector mercantil y la minería, que incrementan su contribución a la recaudación fiscal, mientras que la participación de la agricultura se estabiliza y desaparece el aporte indígena.

Cuadro 4. Ingresos de la Caja Real de Arica por sectores económicos, 1775-1786 (PESOS DE 8 REALES)

\begin{tabular}{|c|c|c|c|c|c|} 
& Agricultura & Comercio & Mineria & Tributo indigena & Total Caja \\
\hline 1775 & 3.693 & 1.390 & & 11.011 & 20.543 \\
1776 & 3.542 & 1.408 & & 10.167 & 17.592 \\
1777 & 4.659 & 2.635 & & 10.448 & 20.066 \\
1778 & 4.239 & 1.778 & & 10.278 & 19.176 \\
1779 & 16.826 & 2.668 & & 20.826 & 51.406 \\
1780 & 10.847 & 1.334 & 94.233 & 11.126 & 121.860 \\
1781 & - & - & - & & - \\
1782 & 5.180 & 23.158 & 32.359 & & 64.415 \\
1783 & 4.274 & 26.185 & 16.734 & & 53.318 \\
1784 & 11.626 & 11.943 & 19.461 & & 48.185 \\
1785 & 12.210 & 7.346 & 29.264 & & 49.917 \\
1786 & 12.476 & 13.298 & 54.496 & & 83.091 \\
\hline Total periodo & 89.572 & 93.143 & 246.547 & 73.856 & 549.569 \\
\hline
\end{tabular}

Fuente: Te Paske y Klein, 1982, vol 2. 
Sobresale la considerable contribución del sector minero a la Real Hacienda que se aprecia a partir de 1779 , año en que se inauguró una fundición de metales (callana) anexa al local de la Caja Real en Tacna, donde debían llevar su producción los mineros del asiento de Huantajaya en la sureña Tarapacá, para ser procesada y gravada con los correspondientes derechos reales. La decisión de localizar una callana en la Caja de Arica y dirigir hacia ella la producción de Tarapacá, fue tomada por el Visitador General del Perú José Antonio de Areche, que llegó al virreinato en junio de $1777^{32}$. Poco antes de adoptarse esta medida, el asiento de Huantajaya ya mostraba un aumento de su producción, estimulado también por la creciente oferta de manufacturas importadas luego de la liberación, en 1778, de las restricciones que pesaban sobre el comercio ${ }^{33}$.

Hasta entonces, la producción tarapaqueña de plata tenía como destino obligado la Caja de Carangas (Alto Perú), aunque algunos mineros obtenían licencias para remitirla a Potosí, Oruro, Lima o Arequipa, donde muchos habían fijado su residencia. Aunque la decisión suponía un perjuicio para los productores tarapaqueños, por las distancias y dificultades geográficas que debían salvar para llegar hasta Tacna, la autoridad justificaba la medida en la necesidad de mitigar los daños provocados a la economía bajoperuana por el traspaso de los yacimientos mineros altiplánicos al virreinato del Plata. Además, la decisión facilitaba la recaudación del impuesto de un real por marco de plata para el sostenimiento del Tribunal de Minería y el Banco de Rescates de Huantajaya ${ }^{34}$. Estas instituciones, creadas en Perú en 1787, tenían por fin reunir fondos para impulsar la modernización de la minería y ofrecer a los productores insumos, como pólvora y azogue, a precios inferiores que los de mercado, y créditos en mejores condiciones que las ofrecidas por los comerciantes ${ }^{35}$. Además, la distribución de azogue permitía fiscalizar la producción, ya que a partir de la cantidad de mercurio retirada se podía calcular la producción de cada minero.

De esta forma y como se aprecia en las cifras recopiladas, durante el período 1775-1786 la minería aportó el 44,9\% del ingreso fiscal ${ }^{36}$, contra el 16,3 de la agricultura, 16,9 del comercio y 13,4 del tributo indígena. Este último

32 Fisher, 2000: 280-281. Palacio Atard, 1946: 9-13.

33 La influencia del comercio sobre la expansión de la minería tarapaqueña es analizada por Villalobos, 1979: 139-140. Otra visión sobre esta relación a nivel del área andina, pero sin conclusiones divergentes, la ofrece Pérez Herrero, 1992: 286-292.

34 Gavira Márquez, 37 (Arica, 2005): 43-44 y 50-51.

35 Contreras, 1999: 23-32.

36 Cifra incluye el ramo de «Azogues». 
dejó de ser computado por los oficiales de Hacienda a partir de 1781, lo que no significa necesariamente que haya desaparecido ${ }^{37}$. Es importante tener en cuenta que aunque la agricultura y el comercio disminuyeron su participación en el total de los ingresos fiscales, su aporte continuó creciendo en términos absolutos, puesto que mientras la primera fue gravada en 1782 con el impuesto a las haciendas y pulperías, y en 1784 con el cobro separado de la alcabala de la tierra, al segundo le fue aplicada la alcabala del viento en 1782 . En el caso de la agricultura, el aumento de su tributación pareciera obedecer más al perfeccionamiento de los mecanismos de recaudación que a una expansión productiva, a diferencia del comercio, donde las nuevas condiciones fiscales efectivamente estimularon su desarrollo. Este supuesto se verifica al constatar el incremento de escrituras notariales relativas a operaciones comerciales entre el partido de Arica y otras regiones del imperio, y a un ostensible aumento de las embarcaciones que llegaban al puerto de Arica desde otras plazas del Pacífico y la Península ${ }^{38}$.

El principal efecto de las transformaciones propiciadas por las reformas fue la incontrastable influencia alcanzada por la minería en la economía regional, teniendo como núcleo la Caja Real, su callana y la distribución de azogue. Además de Huantajaya, la caja atendía otros partidos tarapaqueños, como Challacollo, Yabricoya, Chanabaya y Santa Rosa, y el de la Santísima Trinidad de Mecalaco, en la doctrina de Ilabaya, al noreste de Tacna. En conjunto, estos asientos representaban casi el 5\% de la producción de plata en el Bajo Perú, registrando poco menos de siete millones de pesos entre 1780 y $1804^{39}$, y tributando más de 780.000 pesos, como se aprecia en el siguiente cuadro.

Estas cifras demuestran que durante dicho período el aporte del sector minero constituyó el 37,6\% del ingreso total de la Caja Real de Arica. Salvo 1780 , cuando seguramente se había acumulado una considerable existencia a la espera de ser procesada, los períodos en que se computaron mayores volúmenes de plata registrada, como 1788-1792 y 1796-1798, coinciden con llegadas de remesas de azogue desde España, que lograron mitigar la escasez del producto, tradicionalmente aprovisionado desde Huancavelica, que atendía

37 Araya Bugueño, 35 (Arica, 2003): 149.

38 Esta información se encuentra en el fondo Hacienda de la Sección Colonial del Archivo General de la Nación, del Perú. Aunque los registros de la Aduana de Arica están incompletos, y carecen de síntesis anuales que ofrezcan una visión exacta del volumen del comercio a través de ese puerto, las guías que detallan la carga desembarcada en Arica permiten suponer que entre 1782 y 1793 el intercambio comercial experimentó un período de expansión.

39 Fisher (Lima, 1978): apéndice I. 
Cuadro 5. Plata gravada en la Caja Real de Arica, 1780-1804 (PESOS DE 8 REALES)

\begin{tabular}{|c|c|c|c|c|}
\hline & $\begin{array}{l}\text { Plata } \\
\text { Grazanda }\end{array}$ & $\begin{array}{c}\text { Ingreso } \\
\text { Total Caja (a) }\end{array}$ & $\begin{array}{c}\text { Remesas } \\
\text { (b) }\end{array}$ & $\begin{array}{l}\text { Remanente en Caja } \\
\text { (a) - (b) }\end{array}$ \\
\hline $17 \times 0$ & $87.6 \times 4$ & 161.440 & 39.063 & 122.377 \\
\hline 1781 & - & - & - & - \\
\hline 1782 & 27.060 & 90.873 & - & 90.573 \\
\hline $17 \times 3$ & 12.840 & $53.6 \times 2$ & $35 \ldots \mathrm{MB}$ & 18.374 \\
\hline 1784 & 19.264 & 49.545 & 29.177 & $20.36 \mathrm{x}$ \\
\hline $17 \times 5$ & 22,757 & 52.382 & 37.200 & $15.1 \% 2$ \\
\hline 1786 & 34.749 & 89.735 & 75.250 & 14.485 \\
\hline 1787 & 32.817 & 121.789 & 70.735 & 51.054 \\
\hline $17 \times$ & 43.248 & 120022 & 79.817 & 41.165 \\
\hline $17 \times 9$ & 34,674 & 115012 & 70642 & 44,370 \\
\hline 1730 & 20.576 & 62.454 & 59.831 & 2.623 \\
\hline 1791 & 27.996 & 74.893 & 57.760 & 17.133 \\
\hline 172 & $31, \ddot{x} 58$ & 74.650 & 59.393 & 15.257 \\
\hline 1793 & 30.920 & 82.749 & 56.341 & 26,408 \\
\hline 1794 & 36.544 & 89.422 & 50.737 & 38.685 \\
\hline 1795 & 31.575 & 92.127 & 55.540 & 36.587 \\
\hline 176 & $40.26)$ & 91.525 & $49 . \times 46$ & 41.670 \\
\hline 1797 & 43.672 & 105.174 & 70.526 & 34.648 \\
\hline 1708 & 66.459 & 112.901 & 84.833 & 28.068 \\
\hline 1799 & 35.581 & 83.451 & 54.776 & 28.675 \\
\hline $1 \$ \infty$ & 42.959 & $\$ 9.319$ & 62203 & 27.116 \\
\hline$|\times 0|$ & 24,132 & 64,411 & $3 \times 22$ & 26,189 \\
\hline 1502 & - & - & - & - \\
\hline 1803 & 16.322 & 63.446 & 46.550 & $16.8 \%$ \\
\hline 1804 & $17,6 \times 66$ & 92,624 & $7 \pi 107$ & 15.517 \\
\hline Total periodo & 71.542 & 2.034 .136 & 1.260 .457 & 773.669 \\
\hline
\end{tabular}

Fuente: Te Paske y Klein, 1982, vol 2; Fisher (Lima, 1978): apéndice I.

los requerimientos del Alto y el Bajo Perú ${ }^{40}$. Otra consideración que se desprende de las cifras anotadas, es que el $12,2 \%$ de la plata registrada fue rete-

40 Las cuentas de la Caja Real de Arica recopiladas en Te Paske y Klein, 1992, tabulan por separado el ingreso de mercurios de Almadén y de Huancavelica, de la misma forma como figuran en la documentación original que hemos consultado. Fisher, 1999: 154. 
nida por diferentes gravámenes que debía satisfacer. Esta proporción alcanzó sus máximos en 1788 y 1800 , con un 15,95 y un $17,08 \%$ respectivamente. En el primer caso, la mayor severidad de los oficiales reales en el cobro de derechos parece obedecer a la necesidad de financiar la misión Nordenflycht, que ese año llegó al Perú para impulsar la modernización de la minería, mientras que el segundo coincide con el reinicio de las hostilidades entre España e Inglaterra. Lo anterior demuestra que el sector minero asociado a la Caja de Arica contaba con un nada despreciable potencial de desarrollo, que a su vez servía de estímulo al comercio regional.

Finalmente, el cuadro anterior muestra un considerable volumen de recursos que ingresó en la Caja y que no fue remitido a otras dependencias de la Real Hacienda, con un excedente de poco más de 770.000 pesos a lo largo del período y un promedio anual de 33.637 pesos. Esta suma debía cubrir los gastos ordinarios y extraordinarios de la Corona en el partido de Arica, que consideraba los sueldos y pensiones de funcionarios, quienes a excepción de los oficiales de la Caja Real, sus guardas y el ensayador de la callana (en 1793 sus salarios en conjunto ascendían a 6.400 pesos anuales ${ }^{41}$ ), tenían un ingreso variable correspondiente a un porcentaje del producto de su cargo.

\section{LOS COMERCIANTES APODERADOS}

El flujo de plata hacia la callana de Tacna constituyó, a partir de 1780, un factor fundamental para la consolidación del comercio regional. A diferencia del período anterior, cuando la caja de Arica articulaba el flujo de la plata y el azogue entre Lima y las minas altiplánicas, y sólo una parte ínfima del capital comprometido en el circuito quedaba en la región, la proporción de los recursos circulantes que permanecía en la Caja aumentó considerablemente, al punto de propiciar la aparición de empresarios locales especializados en el comercio. Por el mayor volumen de sus operaciones, los mercaderes locales surgidos al amparo del reformismo borbón desplazaron a los arrieros que se habían aventurado en el comercio a través de la sierra, quienes, incapaces de acumular capital comercial, debieron conformarse con la prestación de servicios de transporte.

Dentro de la nueva normativa y a objeto de fundir su producción en Tacna, los mineros tarapaqueños debían designar a un representante ante los oficiales de la Caja Real, encargado de hacer llegar su producción hasta la callana de Tacna, cancelar las obligaciones tributarias, remitirles las utilidades,

41 Barriga, 1948, t. III: 42. 
obtener azogue y compartir la responsabilidad respecto de que la cantidad de plata en piñas entregada fuera proporcional al mercurio extraído ${ }^{42}$. Estas funciones, atribuciones y responsabilidades quedaban estipuladas en una escritura pública, mediante la cual los mineros entregaban poderes de representación a sus apoderados, quienes además afianzaban con su patrimonio el cumplimiento de todas las obligaciones fiscales comprometidas por sus poderdantes. Aunque ninguno de los documentos de este tipo examinados establece honorarios o comisiones para los apoderados, es probable que los servicios de los agentes tacneños tuviesen alguna remuneración o participación en las ganancias, dados los requisitos que debían reunir los individuos que aspiraban a convertirse en representantes de empresarios mineros ${ }^{43}$. Debían ser personas de reconocido prestigio y honestidad, ofreciendo garantías de administrar con prudencia y rectitud los recursos públicos y privados puestos bajo su tutela; era necesario que conocieran los procedimientos administrativos involucrados para dar fluidez a las operaciones; y además, debían contar con un patrimonio personal suficiente para cubrir las garantías exigidas y solventar los gastos del traslado y almacenamiento de los caudales, cuando no acudir en auxilio de sus mandantes. Junto al vínculo contractual de representación, muchos mineros tarapaqueños añadían facultades generales a sus agentes en Tacna para que atendieran la administración de sus asuntos comerciales y las causas judiciales en que se vieran comprometidos. Además, los apoderados tacneños quedaban en situación de convertirse en proveedores de sus representados, que debían adquirir cantidades no menores de mercadería para atender las necesidades básicas de los operarios a su servicio, así como la demanda en su región por alimentos y efectos de ultramar.

Aunque no es posible confeccionar una lista completa, las piezas disponibles de los registros contables de la Caja Real de Arica ofrecen una visión aproximada del aporte tributario de la minería tarapaqueña, y quienes fueron los personajes que con mayor recurrencia se desempeñaron como intermediarios entre productores y fiscalizadores. Los trámites que realizaban los agentes consistían en la obtención de azogue, ya sea a crédito o al contado; y la satisfacción de los derechos fiscales sobre la producción de plata, como la parte correspondiente al Rey, el real por marco de plata para el Tribunal de Minería, y los costos de fundición y ensaye.

42 Un marco de plata en piña por cada libra de mercurio recibida, BDUCH, Caja Real de Arica, legajo 4, folios 181v-182.

43 Poder general de representación, 18 de abril de 1787, ANHC, Notarial de Tarapacá, legajo 5, folios 50v-51v.; Poder de representación, 21 de agosto de 1799, ANHC, Notarial de Arica, legajo 55, folios $21 \mathrm{v}-22 \mathrm{v}$. 
Entre 1781 y 1802 doce personas realizaron operaciones de intermediación, de los cuales sólo tres, Narciso Infantas y Vargas, Joaquín González Vigil y Vicente Ballon, persistieron en el tiempo y comprometieron suficiente capital, como para afirmar que la representación de mineros era una de sus ocupaciones principales. Otros eran vecinos de Tarapacá que cumplieron encargos o participaron en sociedades mineras, en las que se encargaban de diversos trámites; o bien, mercaderes de Tacna, que ocasionalmente se desempeñaron como apoderados de mineros intentando hacerse un lugar en la actividad, ofreciendo condiciones menos severas que los agentes más connotados o, como una forma de complementar otras prestaciones para sus clientes ${ }^{44}$.

De aquellos que se consolidaron como apoderados de mineros y azogueros tarapaqueños ante la Caja Real de Arica, el más destacado fue Joaquín González Vigil, que logró reunir la mayor fortuna de Tacna de la última década del siglo XVIII, siendo además un ejemplo exitoso de adaptación al orden político y económico impuesto por los reformadores borbónicos, combinando equilibradamente funciones burocráticas y emprendimientos económicos. De su trayectoria empresarial sobresale una lógica mercantil distinta a la de otros comerciantes, que condicionados por sus raíces en la arriería, la única forma de acumulación que concebían era la adquisición de mulas y tierras. González en cambio, reinvirtió sus utilidades en el comercio y la minería.

Nacido en Sevilla de padre asturiano y madre andaluza, Joaquín González Vigil dictó su testamento en Tacna el 2 de noviembre de 1818, en el que legó a su viuda y nueve hijos la principal fortuna de esa villa. Aunque el documento no detalla el monto total de su herencia, es posible inferir su volumen a partir de algunos datos allí consignados. Por ejemplo, declara que al desposar a Micaela Yañez contaba con un capital de 30.000 pesos en plata acuñada y barras ensayadas, suma que sobradamente permitía considerarlo un hombre acaudalado. Además, como regalo obsequió a su mujer joyas avaluadas en 700 pesos y dos esclavas que adquirió en 400 pesos. Un aspecto que llama la atención en su testamento es que, a diferencia de otros comerciantes tacneños, no menciona mulas ni propiedades agrícolas. Sólo señala la chacra Peñablanca en el valle de Tacna, que estaba plantada con olivares y frutales, con fines ornamentales más que productivos. En cambio, dedica más espacio a dar cuenta de sus intereses mineros en el asiento de Mecalaco, donde poseía algunas estacas, un trapiche y acreencias por casi 10 mil pesos. Sin embargo, la porción más importante de su herencia correspondía a cuentas por cobrar

44 BDUCH, Caja Real de Arica, legajos 4 y 5. 
en Tarapacá. Además, tenía una casa habitación en el centro de Tacna, finamente amoblada y alhajada, y servida por tres esclavas y dos esclavos ${ }^{45}$.

González llegó al partido de Arica al comenzar la década de 1770, como parte de la comitiva del corregidor Demetrio Egan, a quien asistía como secretario y contador. En virtud de ser un hombre instruido, en mayo de 1779 fue designado Administrador del Correo, un destino que si bien era pobremente remunerado (135 pesos anuales, más un porcentaje de los trámites ${ }^{46}$ ), le permitió conocer y darse a conocer en toda la provincia, y adentrarse en los mecanismos de la administración colonial, ya que entre sus funciones estaba enviar las remesas de la Caja Real de Arica a sus similares en Arequipa y Lima. Además, en 1781 se desempeñó interinamente como Contador de la caja de Arica, cuando ésta ya administraba la distribución de mercurio y la callana ya funcionaba ${ }^{47}$. Esta experiencia lo calificó para desempeñarse como agente intermediario.

La primera operación que realizó como representante tuvo lugar el 15 de mayo de 1782, cuando compró 9 quintales de azogue para el minero de Mecalaco Juan Pedro Exlemburu ${ }^{48}$, con quien colaboró hasta 1797, aunque ocasionalmente éste recurrió a otros agentes ${ }^{49}$. En cambio, González Vigil tuvo permanentemente la responsabilidad de hacer llegar las piñas de plata a la fundición, pagar derechos reales y enviar las utilidades ${ }^{50}$. Hacia fines de 1785 Joaquín González Vigil logró extender sus operaciones a Tarapacá, obteniendo 10 quintales con 5 libras de azogue para el minero de Huantajaya Joseph Gómez; al año siguiente prestó el mismo servicio a Matías de Soto, Lucas Bravo y Alberto Zevallos, mediante operaciones de crédito a seis meses ${ }^{51}$.

Hasta entonces González era uno más entre los que se desempeñaban como apoderados, compartiendo el mercado con otros mercaderes de la plaza. Sin embargo, a partir de 1786 comenzó a concentrar una proporción cada vez

45 Testamento de Joaquín González Vigil, 26 de abril de 1819, ANHC, Notarial de Tacna, legajo 8 , folios 311-322.

46 Fianza, 1 de febrero de 1781, BDUCH, Caja Real de Arica, legajo 4, fol. 140.

47 Despachos de remesas a la Caja Real de Arequipa, octubre a noviembre de 1781, BDUCH, Caja Real de Arica, legajo 4, folios 135v a 157.

48 Retiro de azogue, 15 de junio de 1782, BDUCH, Caja Real de Arica, legajo 4, folios 180-180v.

49 Retiros de azogue, marzo y septiembre de 1785 y agosto de 1786, CRA, leg 4, fol. 78v; folios 190-190v, 193v, 195 y 198.

50 Entregas de piñas de plata, 20 de marzo de 1785 y 17 de marzo, 1796, BDUCH, Caja Real de Arica, legajo 4, folios $185 \mathrm{v}-186$, legajo 5, folios $335 \mathrm{v}$ y $355 \mathrm{v}$.

51 Entregas de piñas de plata, diciembre de 1785 a agosto de 1786, BDUCH, Caja Real de Arica, legajo 4, folios 197v, 198v, 199v y 201. 
mayor de las operaciones, sólo superado por Narciso Infantas. En este sentido, resultó fundamental para Vigil la relación establecida con Sebastián Talledo, en cuya representación, durante 1788 , pagó 6.780 pesos en tributos por 30 barras de plata en piña que rindieron poco más de 40.000 pesos ensayados ${ }^{52}$.

Otra relación provechosa fue la que estableció con Josef de Córdova, minero de cierta importancia, y además gobernador de Tarapacá y administrador del Banco de Rescates de Minas de ese partido, que distribuía mercurio y coordinaba a otros empresarios para el despacho de su producción a Tacna. Llama la atención que a partir de las primeras operaciones hechas como representante de Córdova y el Banco de Rescates en 1788, la cartera de clientes de González Vigil se ampliara considerablemente con la incorporación de varios pequeños y medianos mineros. Sin embargo, la fortaleza de su posición radicaba en la representación de grandes productores, tales como Gregorio Morales, Matías González Cossio, Matías, Francisco y Valentín de la Fuente, que nunca remitían a Tacna menos de diez barras de plata ${ }^{53}$. En definitiva, al examinar la progresión de las operaciones de Joaquín González Vigil como apoderado de mineros tarapaqueños, se constata que alcanzó su mayor nivel de influencia durante la segunda mitad de la década de 1790, justo cuando los yacimientos del partido de Tarapacá alcanzaron su máximo rendimiento.

El vínculo de González Vigil con la minería no fue sólo como agente, ya que también se involucró en explotaciones, al punto que, en julio de 1793 el Intendente de Arequipa lo menciona como propietario de la mina San Francisco de Paula en Ilabaya ${ }^{54}$. Las primeras evidencias de sus inversiones mineras se remontan a enero de 1785 , cuando extendió poderes de representación a Diego Siles para obtener en la Caja Real 8 quintales con 97 libras de azogue de Huancavelica, a objeto de beneficiar la producción de su mina de Mecalaco. El mercurio extraído tenía un valor de 538 pesos, suma que debía ser restituida en nueve meses ${ }^{55}$. La operación se repitió en noviembre y diciembre de ese año, cuando Siles retiró nuevas partidas de azogue ${ }^{56}$, lo que indica que

52 Pago de derechos reales, junio a diciembre de 1788, BDUCH, Caja Real de Arica, legajo 5 , folios $81,84 \mathrm{v}-85,90 \mathrm{v}-91,93 \mathrm{v}-94,97 \mathrm{v}-98$ y $102 \mathrm{v}-103$.

53 Entregas de piñas de plata, 17 de marzo y 2 de mayo de 1788, BDUCH, Caja Real de Arica, legajo 5, folios 68-68v y folios 73v-74; Rescate de azogue, 3 de diciembre, 1792, ANHC, Notarial de Arica, legajo 48, folios 237-238.

54 Barriga, 1948, t. II: 330.

55 Rescate de azogue, 2 de enero, 1785, BDUCH, Caja Real de Arica, legajo 4, folios $188-188 \mathrm{v}$.

56 Rescates de azogue, 1 de noviembre y de diciembre de 1785, BDUCH, Caja Real de Arica, legajo 4, fol. 194v y fol. 196. 
las faenas fueron más exitosas de lo previsto y el mercurio antes rescatado se hizo insuficiente.

En 1786 intentó extender sus inversiones mineras asociándose con Josef Murrieta, para adquirir estacas e instalar un trapiche en Mecalaco, en cuya representación González obtuvo 15 quintales de azogue ${ }^{57}$. Por su testamento se sabe que el intento fracasó, ya que la sociedad duró menos de un año; Murrieta quedó con una deuda de 7 mil pesos y González Vigil conservó la propiedad del molino. En adelante, sus emprendimientos mineros contaron con la asistencia de Diego Siles ${ }^{58}$, ya sea para obtener azogue o para afianzar a Alberto Zela y Neira en el cargo de fundidor, ensayador y balanzario de la callana de Tacna ${ }^{59}$, ocupación altamente sensible para todo empresario minero del período tardo colonial.

Además de la relación con Siles, González Vigil delineó su perfil comercial a partir de sus contactos dentro y fuera del partido de Arica. Sus emprendimientos mercantiles comenzaron junto con los de agente de mineros. Una de las primeras oportunidades que aprovechó fue incursionar en la compraventa de los esclavos que arribaban a América por Buenos Aires y Montevideo, y que los comerciantes tacneños podían adquirir en el Alto Perú para luego vender localmente. Es así como en agosto de 1781 vendió un esclavo, adquirido en La Paz, al tesorero de la Caja Real Ramón de Arriaga ${ }^{60}$. Cuatro años más tarde realizó una operación similar, ahora como representante del potosino Lamberto Sierra, vendiendo una negra y sus dos hijas a Apolonia Infantas en 350 pesos $^{61}$.

Aunque el comercio negrero ofrecía perspectivas de buenas ganancias, lo limitado del mercado regional persuadió a González de no especializarse en él. En general, este tipo de operaciones se restringieron a aprovechar ofertas y adquirir personal para el servicio de su familia. En julio de 1801 envió un representante a Potosí para adquirir un bozal de catorce años en 450 pesos, en el remate de los bienes de José Vicente Zavala, que obsequió $202 \mathrm{v}$.

57 Rescate de azogue, 25 de septiembre, 1786, BDUCH, Caja Real de Arica, legajo 4, fol.

58 Rescate de azogue, 8 de marzo de 1787, ANHC, Notarial de Arica, legajo 42, folios $54 \mathrm{v}-55 \mathrm{v}$; Entrega de poderes de representación judicial y comercial, 22 de febrero de 1788, ANHC, Notarial de Arica, legajo 43, folios 39-39v

59 Fianza, 26 de abril de 1788 y 16 de febrero de 1789, ANHC, Notarial de Arica, legajo 43 , folios $79-80$ y legajo 45 , folios $49-49 \mathrm{v}$.

60 Venta de esclavo, 27 de agosto de 1781, ANHC, Notarial de Arica, legajo 41, folios $422-423 \mathrm{v}$.

61 Venta de esclavo, 13 de mayo de 1785, ANHC, Notarial de Arica, legajo 44, folios $262 \mathrm{v}-267$. 
luego a su hijo Miguel ${ }^{62}$. Otra coyuntura favorable se presentó en mayo de 1816, cuando llegó a Tacna una columna del ejército realista conduciendo veinte esclavos que debían venderse para contribuir al financiamiento de las armas del Rey. En dicha ocasión adquirió un robusto varón en 250 $\operatorname{pesos}^{63}$.

No obstante la amplitud de sus intereses, la fortaleza de González Vigil estaba en su relación con los mineros tarapaqueños. Además de representarlos ante la Caja Real, los habilitaba con manufacturas, alcohol y alimentos, que empleaban para pagar los salarios de sus trabajadores y distribuir en sus áreas de influencia, en las que disfrutaban la posición de mercaderes monopólicos. Un caso de este tipo es el vínculo que González Vigil sostuvo con el minero y azoguero tarapaqueño Matías González Cossio, a quien proporcionaba grandes partidas de efectos elaborados que le eran pagados luego de ser vendidos al detalle, como consta en una escritura que Cossio suscribió para adquirir mercaderías por valor de 5 mil pesos ${ }^{64}$.

Para abastecerse de los diversos artículos que ofrecía, González Vigil recurría a sus relaciones con el comercio limeño forjadas durante el desempeño de funciones administrativas, ya sea aprovechando las recaladas en Arica de navíos de permiso provenientes de España, o bien, encargando a Lima productos para el consumo de los segmentos sociales altos. Este fue el caso de las 25,5 arrobas de chocolate y un cajón de libros que recibió a bordo de la fragata Nuestra Señora de los Dolores en diciembre de 178865, los 132 zurrones de añil de Acajutla en el paquebote El Dichoso en octubre de $1796^{66}$, las 130 arrobas de chocolate de Guayaquil en el paquebote Centella en abril de 179767, las 280 arrobas de chocolate que Raimundo Suárez le envió desde Lima a bordo del paquebote Gran Señor en marzo de $1803^{68}$, y los 307 quin180.

62 Venta de esclavo, 16 de julio de 1801, ANHC, Notarial de Arica, legajo 58, folios 178-

63 Venta de esclavo, 7 de mayo de 1816, ANHC, Notarial de Arica, legajo 64, folios $72-$ $75 \mathrm{v}$.

64 Adelanto de mercadería, 16 de junio de 1794, ANHC, Notarial de Arica, legajo 50, folios $94 \mathrm{v}-96$.

65 Retiro de mercadería, 14 de diciembre de 1788, Archivo General de la Nación del Perú (AGNP), Real Aduana de Arica, legajo 116, cuaderno 198.

${ }^{66}$ Retiro de mercadería, 12 de octubre de 1796, AGNP, Real Aduana de Arica, legajo 128, cuaderno 183.

${ }^{67}$ Retiro de mercadería, 10 de abril de 1797, AGNP, Real Aduana de Arica, legajo 128, cuaderno 183.

68 Retiro de mercadería, 8 de marzo de 1803, AGNP, Real Aduana de Arica, legajo 132, cuaderno 222. 
tales de hierro que la fragata de guerra Esmeralda trasladó en sus bodegas desde El Callao en diciembre de $1818^{69}$.

A diferencia de la mayor parte de los mercaderes tacneños, que adquiría los efectos de ultramar llegados al Atlántico en diversas plazas altoperuanas a través de las rutas de arriería, González Vigil obtenía manufacturas en Lima, cuyo comercio seguía controlando las mercancías que ingresaban a América por la ruta del Pacífico, y resistía la competencia de bonaerense abasteciéndose en Panamá, plaza frecuentada por contrabandistas británicos establecidos en Jamaica ${ }^{70}$. Los antecedentes contenidos en los expedientes notariales y en la contabilidad fiscal, demuestran que las manufacturas ingresadas por el Río de la Plata arribaron masivamente a Tacna después de la promulgación del Reglamento de Libre Comercio en 1778, sin embargo la influencia del comercio limeño permaneció durante el resto del período colonial, gracias a que la regularidad en su aprovisionamiento no estaba sometida a los vaivenes de la política exterior española ${ }^{71}$.

Como todo mercader colonial, González Vigil operaba con otros comerciantes formando redes de apoderados y representantes, que permitían a sus miembros mantenerse abastecidos de los artículos que podrían ser fácilmente colocados en los mercados a que tenían acceso, en tanto que asumían la tarea de remitir a otros asociados las mercancías producidas localmente. Es decir, González Vigil recibía efectos de ultramar y productos alimenticios desde otros rincones de la América española, y despachaba vino, aguardiente, aceite y ají. Para participar en este circuito recurría a la colaboración de apoderados, como Manuel Martín Romaña en Arequipa, y Manuel Suárez Inclán en Lima, que se encargaban de supervisar los embarques y desembarques de mercadería, vigilar las remesas de caudales y ajustar cuentas con sus asocia$\operatorname{dos}^{72}$.

Otra actividad que asimilaba el perfil comercial de Joaquín González Vigil al de otros comerciantes tacneños, era la de habilitar a arrieros que acudían a los mercados altoperuanos transportando mercaderías por su cuenta. En marzo de 1795 hizo un préstamo de mil pesos a Tomás de Soto y su hijo Urbano, para organizar un envío de aguardiente. Los arrieros se comprometieron a

${ }^{69}$ Retiro de mercadería, 24 de diciembre de 1818, AGNP, Real Aduana de Arica, legajo 155 , cuaderno 392.

70 Pierce, 2007: 64-65.

71 Fisher, 2000: 120-121.

72 Poderes de representación comercial y judicial, 12 de marzo de 1804, ANHC, Notarial de Arica, legajo 60, folios 216-216v; Poderes de representación comercial y judicial a Manuel Suárez Inclán, 1 de febrero de 1805, ANHC, Notarial de Arica, legajo 61, folios 210v-211. 
pagar 100 pesos después cada uno de los próximos diez viajes que realizaran y llevar en cada expedición siete cargas de aguardiente pertenecientes a Vigil $^{73}$. En octubre del mismo año Pedro Coria y su mujer reconocieron un préstamo recibido de González Vigil por 2 mil pesos, destinados a comprar mercaderías para colocar en la sierra. El matrimonio se comprometió a devolver 700 pesos luego de sus próximos tres viajes y permitirle trasladar productos en ellos sin costo alguno ${ }^{74}$.

Es probable que González Vigil haya participado en otras operaciones de habilitación que no fueron formalizadas, ya que en una sociedad pequeña y en la que todos se conocían, la mayor parte de este tipo de convenios se celebraba verbalmente, por lo que es frecuente encontrar en los testamentos referencias a acuerdos comerciales carentes de respaldo legal. Aunque González Vigil fue un hombre que se desempeñó toda su vida en el ámbito de lo formal, también debió ajustarse a los cánones del mundo tradicional. Esta situación tenía lugar especialmente cuando trataba con sujetos dedicados al intercambio en pequeña escala, como los arrieros comerciantes, que acudían a él en procura de mercaderías y crédito. La presencia de estos singulares empresarios se fue atenuando en la medida que el siglo XVIII finalizaba, desplazados por mercaderes especializados que, como González Vigil, controlaban grandes volúmenes de mercancías, ofrecían mejores precios, disponían de información fresca sobre los mercados y estaban en condiciones de copar todos los flujos comerciales que involucraban artículos elaborados y bienes provenientes de regiones distantes y con mayores márgenes de utilidad. Por lo tanto, los arrieros comerciantes dejaron de ser atractivos para la colocación de créditos, quedaron relegados a la venta de licores y vinos, y con el tiempo, debieron especializarse en el transporte y renunciar a sus ambiciones mercantiles.

\section{Conclusiones}

Posicionado geográficamente para participar en los flujos de intercambio de materias primas e importaciones, el eje Tacna-Arica se convirtió, durante las dos últimas décadas del siglo XVIII y la primera del siglo XIX, en una encrucijada comercial. Allí confluían los bienes importados que llegaban por

73 Préstamo a Tomás y Urbano de Soto, 3 de febrero de 1795, ANHC, Notarial de Arica, legajo 51, folios $11 \mathrm{v}-13 \mathrm{v}$.

74 Préstamo a Pedro Coria, 3 de octubre de 1795, ANHC, Notarial de Arica, legajo 51, folios 238-238v. 
las rutas del Pacífico y la sierra, los alimentos procedentes de Chile, norte de Perú y Guayaquil, para consumo de las ciudades y enclaves mineros del altiplano, la demanda tarapaqueña por manufacturas e insumos básicos, mercaderes arequipeños y moqueguanos en procura de importaciones, y la producción regional de alimentos, aceite, vino, aguardiente y forraje, al encuentro de un amplio abanico de compradores.

El ambiente económico generado por las reformas borbónicas, no modificó sustantivamente la estructura económica tacnoariqueña, en cuanto a que continuó basada en la agricultura y la arriería, pero permitió que durante las décadas de 1780 y 1790 algunos arrieros incursionaran en el comercio hasta conformar un incipiente sector mercantil, cuya dinámica rebasó el ámbito únicamente local. El núcleo de sus actividades continuó descansando en el traslado de la producción regional hacia el Alto Perú y Tarapacá. Este comenzó a ser complementado con el transporte de otros productos más rentables, como manufacturas de ultramar, tintes centroamericanos y cacao de Guayaquil, para cuyo abastecimiento los mercaderes tacnoariqueños dependían de núcleos comerciales más gravitantes, como Lima, Potosí, Buenos Aires e incluso Arequipa.

Esta transición fue posible porque la desaparición de la figura del Corregidor y la institución del repartimiento dejó un espacio para que arrieros y agricultores emprendieran algunas actividades mercantiles. Ninguna de estas experiencias derivó en una empresa comercial consolidada, autónoma y formal, puesto que sus utilidades no fueron reinvertidas en el comercio y no trascendieron a sus fundadores; los herederos tendieron, mayoritariamente, a retornar a la arriería y la agricultura, incorporarse en la burocracia, o simplemente a vivir de las rentas, consumiendo el exiguo patrimonio acumulado por sus padres.

En cambio, la creación de una fundición de plata junto a las oficinas de la Caja Real de Arica, la obligación de los mineros de Tarapacá de enviar ahí su producción, la posibilidad de obtener azogue en esas mismas dependencias y la consiguiente necesidad de nombrar un representante, atrajeron a actores de mayor envergadura que sencillos troperos o campesinos, y dieron lugar a la consolidación del comercio tacnoariqueño. Además de obtener un pago por sus servicios, algunos de estos mercaderes accedieron a clientes tarapaqueños que constantemente requerían ser provistos de manufacturas y alimentos, ampliando la limitada demanda local y regional, y los siempre inciertos mercados altoperuanos. De esta forma, el vínculo con la minería tarapaqueña permitió que, por un tiempo, los comerciantes tacnoariqueños controlaran los flujos de intercambio que transitaban por la región y comenzaran a acumular capital mercantil. 
El acceso a una porción de las utilidades de la minería no sólo incentivó la expansión del comercio tacnoariqueño, sino que además persuadió a las elites regionales de la directa influencia que tenían las políticas imperiales para el desarrollo de la economía del territorio y, por lo tanto, de la necesidad de hacer valer políticamente sus interese frente a la presencia de actores de mayor tamaño e influencia.

Esta amenaza se consumó en el transcurso de la década de 1790, ya que los rentables vínculos establecidos con la minería tarapaqueña y los mercados altoperuanos, atrajo la llegada a la región de redes mercantiles limeñas y españolas. Estas, gracias a controlar una mayor oferta, ofrecer precios inferiores, entregar crédito y contar con el apoyo de las autoridades virreinales, desplazaron a parte importante de los comerciantes locales, obligándolos a retornar a la arriería, la agricultura, a integrarse como agentes locales, o a limitarse a atender mercados marginales.

En definitiva, el conjunto de las medidas administrativas impulsadas por los reformadores borbónicos generó condiciones que facilitaron el desarrollo del comercio tacnoariqueño y estimuló el surgimiento de un grupo de empresarios regionales especializados. Este segmento mercantil estaba consciente de la influencia que tuvieron las decisiones políticas en el desenvolvimiento de sus propios negocios, por lo tanto y en lo sucesivo, en ese ámbito buscaron respuestas a las dificultades económicas que enfrentaron. Bajo este criterio, los movimientos anticoloniales que tuvieron lugar en la región se explicarían como una estrategia de su elite mercantil para enfrentar la competencia de las redes comerciales limeñas y peninsulares, así como los alzamientos contra la temprana república peruana reflejarían la intención de imponer al naciente Estado un régimen normativo favorable a sus intereses.

\section{BIBLIOGRAFÍA}

Araya Bugueño, Manuel, "Fiscalidad y economía regional: Arica 1759-1799", Chungará, 35 (Arica, 2003): 121-157.

Barriga, Víctor. Memorias para la Historia de Arequipa, 3 tomos, Arequipa, Editorial La Colmena, 1941-1948.

Cavagnaro, Luis, Tacna: Desarrollo urbano y arquitectónico (1536-1880), Tacna, CETICOS, 2000.

Contreras, Carlos, "La minería peruana en el siglo XVIII”, Scarlett O`Phelan (comp.), El Perú en el siglo XVII. La era borbónica, Lima, Pontificia Universidad Católica del Perú, Instituto Riva Agüero, 1999: 13-35. 
Fisher, John, "La producción de plata en el Virreinato del Perú, 1776-1824", Francisco Miró y otros (eds.), Historia, Problema y Promesa, Lima, Pontificia Universidad Católica del Perú, 1978, vol. I: 255-273.

Fisher, John, Gobierno y sociedad en el Perú colonial. El régimen de las Intendencias, 1784-1814, Lima, Pontificia Universidad Católica del Perú, Fondo Editorial, 1981.

Fisher, John, El Perú Borbónico, Lima, Instituto de Estudios Peruanos, 2000.

Garavaglia, Juan Carlos y Marchena, Juan, América Latina de los orígenes a la independencia, 2 vols., Barcelona, Crítica, 2005.

Gavira Márquez, María Concepción, "Producción de plata en el mineral de San Agustín de Huantajaya (Chile), 1750-1804", Chungará, 37 (Arica, 2005): 37-57.

Hidalgo, Jorge, "Algunas notas para el estudio del olivo en Arica", Idesia, 12 (Arica, 1993): 31-50.

Moreno Cebrián, Alfredo, El Corregidor de Indios y la Economía Peruana del siglo XVIII (los repartos forzosos de mercancías), Madrid, CSIC, 1977.

Morghen, R. P, "Carta del R. P. Morghen, misionero de la Compañía de Jesús, al señor Marques de Reybac", Boletín del Instituto Riva-Agüero, 12 (Lima, 1982-1983): 288296.

Palacio Atard, Vicente. Areche y Guirior, Observaciones sobre el fracaso de una visita al Perú, Sevilla, CSIC, 1946.

Pérez Herrero, Pedro, Comercio y mercados en América Latina Colonial, Madrid, MAPFRE, 1992.

Pierce, Adrian J., British Trade with Spanish America, Liverpool, Liverpool University Press, 2007.

Seiner, Lizardo, "Un caso de complementariedad económico-administrativa en el sur andino: Tacna y Arica (siglos XVI-XIX)", Academia Nacional de la Historia. Pueblos, provincias y regiones en la Historia del Perú, Lima, Academia Nacional de la Historia, 2006: 869-909.

Te Paske, John J. y Klein, Herbert, The Royal treasuries of the Spanish Empire in America, 5 vols., Durham, Duke University Press, 1982.

Fecha de recepción: 11 de junio de 2012.

Fecha de aceptación: 20 de diciembre de 2012. 


\section{From muleteers to merchants. Origins of traders in the Tacna-Arica region, 1776-1794}

This article analyzes the effects of the Bourbon reforms in the province of Arica, in the Viceroyalty of Peru, and examines the economic context that they created and in which a few people engaged in transport activities managed to become small traders.

Key Words: Viceroyalty of Peru, 1776-1794; province of Arica; Bourbon reforms; economy; transport; trade; merchants; muleteers. 